\title{
7 \\ South Korea: The Limits of Operational Integration
}

\author{
Seukhoon Paul Choi
}

'Forged in the crucible of war', the alliance between the Republic of Korea (ROK) and the United States has two mottos: 'we go together' and ready to 'fight tonight'. Beyond mere rhetoric, the alliance consists of a deeply integrated defence posture with a combined warfighting headquarters, bilaterally agreed-upon operational plans (OPLANs) and a 28,000-strong forward-deployed US military presence working side-by-side with half a million active-duty ROK service members.

Despite this close military cooperation, the alliance finds itself in crisis. 'The fight' for which the alliance must prepare has changed. The return of great power competition and the dawn of the second nuclear age have transformed the strategic environment. Escalation dynamics are shifting both below and above the traditional threshold of war and with greater integration of other instruments of national power. These developments present complex political-military challenges, complicating alliance coordination in defending ROK and US collective interests.

This chapter will examine ROK and US management of political-military tensions in their preparations for common defence from a South Korean perspective. It will do so in the context of the alliance's two major challenges: the rise of China and advances in North Korea's asymmetric military capabilities. It will also identify shortcomings in alliance efforts to realise strategic agreement on effective management of escalation across 
the spectrum of competition, crisis and conflict, and highlight alliance political-military mechanisms that, if refitted, could be used to address these gaps.

From an increasingly tense Sino-US rivalry to a North Korean nuclear threat with intercontinental reach, the environment in which the ROK-US alliance operates has become more dangerous and complex. China and North Korea have advanced strategies and fielded capabilities to offset traditional US and alliance advantages. They are exploiting asymmetries in the stakes involved and thresholds of risk not only with, but also between, South Korea and the US. This context raises the importance of cooperation but makes alliance cohesion more difficult. In particular, several political-military challenges constrain the alliance's ability to plan for three important escalatory pathways to and in war: 1) China's intervention in a Korean Peninsula contingency; 2) a regional Sino-US conflict that draws in the alliance; and 3) ROK, US and Japanese responses to North Korea's increasingly sophisticated nuclear and missile force posture.

\section{The China Challenge}

From Beijing's perspective, North Korea's nuclear sites along its border, weapons proliferation, the potential mass inflow of refugees, the forward-deployed presence of US forces and the ROK-US alliance all pose strategic risks, especially in the context of crisis or active war on the Korean Peninsula. ${ }^{1}$ Given China's national interests, there are a range of assessments on the likely role of China in numerous contingencies. These include cooperative involvement to interference or intervention that has China in direct military conflict with South Korea or the alliance. This variance poses political-military challenges to alliance planning. For example, some in the US with a non-proliferation focus and concern about ROK nuclear ambitions, may prefer to cooperate with China, as a permanent member of the United Nations (UN) Security Council and recognised nuclear power under the Treaty on the Non-Proliferation of Nuclear Weapons (NPT), in securing nuclear sites-especially those just south of its border. Despite South Korean concern over 'loose nukes',

1 Currently the Korean Peninsula is in a state of 'suspended war'; the 1950-53 conflict ended in an armistice rather than a declaration of peace. 
many, particularly in the ROK military, would not welcome infiltration of the peninsula by the People's Republic of China (PRC). Respective ROK and US priorities, as they influence whether each ally's interests converge or diverge with those of China, thereby complicate alliance efforts to forge a collective approach to the escalation of a peninsular scenario to involve PRC intervention.

Ambition for regional hegemony and Korea's geostrategic importance also incentivise Beijing to project its power and influence in peacetime through various means and escalatory tactics. These include ongoing information operations and economic coercion to the threat of force. China demonstrated such behaviour in its escalatory, albeit non-military, response to the 2016 US deployment of a Terminal High Altitude Area Defense (THAAD) system to South Korea. Despite this deployment having been an alliance decision to strengthen deterrence and defence against North Korea's nuclear and missile threat, China argued that the system's AN/TPY-2 radar threatened its own nuclear deterrent capability vis-a-vis the US. ${ }^{2}$ Thus, it proactively reframed the issue as one between China and the US, inspiring debate in South Korea and challenging the alliance. Further, in addition to conducting cyber attacks and applying diplomatic pressure on South Korea, China most notably exacted costs on the ROK economy estimated at US\$7.5 billion. ${ }^{3}$

While the ROK decided to host the THAAD battery against PRC protests, South Koreans were nevertheless traumatised by the significant costs China imposed on the country in retaliation. This worsened ROK perceptions of China, catalysing ROK efforts to reduce its economic dependency on China and to build relations with other countries. However, it also inspired perceptions of US abandonment, as the US response to PRC retaliation seemed limited to diplomatic statements and absent actions to counter such coercion or mitigate the economic damage. ${ }^{4}$ Scarred and uncertain of concrete US support, South Koreans have subsequently

2 Ethan Meick and Nargiza Salidjanova, 'China's Response to US - South Korean Missile Defense System Deployment and its Implications', US-China Economic and Security Review Commission Staff Research Report, 26 July 2017, 5, www.uscc.gov/research/chinas-response-us-south-koreanmissile-defense-system-deployment-and-its-implications.

3 Victoria Kim, 'When China and US Spar, It's South Korea that Gets Punched', Los Angeles Times, 19 November 2020, www.latimes.com/world-nation/story/2020-11-19/south-korea-china-beijingeconomy-thaad-missile-interceptor; Meick and Salidjanova, 'China's Response to US - South Korean Missile Defense System', 7-8.

4 Brad Glosserman, 'Seoul Draws Wrong THAAD Lessons', Japan Times, 27 January 2020, www. japantimes.co.jp/opinion/2020/01/27/commentary/japan-commentary/seoul-draws-wrong-thaad-lessons/. 
felt an increased need to, diplomatically at least, accommodate if not appease China's position. This was reflected in Seoul's 2017 messaging to Beijing: a policy of no additional THAAD battery deployments, no ROK integration into a US-led regional missile defence system and no trilateral alliance with the US and Japan. Although none of these options was the subject of alliance discussions or even realistic at the time, this policy inspired US concern that South Korea was conceding too much and drawing too close to Beijing. ${ }^{5}$

Not only does Sino-US strategic competition increase the likelihood of PRC intervention on the Korean Peninsula, but also it raises the risk that regional conflict may escalate horizontally, thus impacting the alliance, if not directly involving US and ROK forces. Despite North Korea being the dominant focus of US Forces Korea (USFK), both permanently and rotationally stationed US forces on the peninsula support the US doctrine of 'strategic flexibility' and could be employed to support regional crisis or war. This makes USFK and South Korea a target during such contingencies.

It is not only critical that the alliance plan for such scenarios, but also coordination is needed between the two allies to address the second-order effects of ongoing US preparations for conflict with China. As the US continues adapting its defence strategy, forces and doctrine to address China in scenarios beyond the peninsula, it is unclear in South Korea what impact this will have for the combined ROK-US alliance's deterrence and defence posture. From the US discontinuing its Continuous Bomber Presence and operationalising its Dynamic Force Employment concept to revising its Unified Command Plan and redesigning its Global Force Management strategy, these changes that impact South Korea and alliance planning are often only explained after completion. ${ }^{6}$

5 Troy Stangarone, 'Did South Korea's Three Noes Matter? Not So Much', The Diplomat, 30 October 2019, thediplomat.com/2019/10/did-south-koreas-three-noes-matter-not-so-much/.

6 For ROK perceptions of, and initial angst about, the US transition from Continuous Bomber Presence to Dynamic Force Employment, see S. Paul Choi, 'Deterring North Korea: The Need for Collective Resolve and Alliance Transformation', 38 North, 23 July 2020, www.38north.org/2020/07/ spchoi072320/. For reporting on Unified Common Plan and ongoing US defence reform, see Theresa Hitchens, 'Exclusive: Milley to OK New Unified Command Plan; Defines SPACECOM's Roles', Breaking Defense, 26 August 2020, breakingdefense.com/2020/08/exclusive-milley-to-signnew-unified-command-plan-defines-spacecoms-roles/. 
In South Korea, like in the US, China is increasingly perceived as a challenge to ROK interests. In both 2018 and 2019, polling conducted by the Seoul National University Institute for Peace and Unification Studies revealed South Koreans considered China the most threatening country to peace on the Korean Peninsula. ${ }^{7}$ Relatedly, in October 2020, a Pew Research Center survey found that 75 per cent of South Koreans had an unfavourable opinion of China and 83 per cent had 'no confidence in Chinese President Xi Jinping to do the right thing regarding world affairs'. ${ }^{8}$

These public attitudes are reflected in changes to ROK defence policy and force development, which are now aimed not only at North Korea, but also at South Korea's 'omnidirectional threats'. strategists are designing concepts that leverage conventional capabilities with strategic effects. South Korea, incorporating the reality of its limitations, is implementing force improvement measures aimed at employing increasingly advanced means in asymmetric ways to counter China. ${ }^{10}$ Despite these tangible defence preparations, successive ROK administrations have preferred a diplomatic strategy that hedges and aims to balance cooperation with its sole treaty ally and its increasingly powerful neighbour. With China's geopolitical significance and unique influence over North Korea, South Korea—while unwavering in its commitment to its US alliance-maintains a less confrontational approach to Beijing than the US. Paradoxically, South Korea's 'strategic ambiguity' on issues that

7 '통일의식조사’ [Tongil Euisik Josah or A Survey of Attitudes towards Unification] (Seoul: Seoul National University Institute for Peace and Unification Studies, 2019), 154.

8 Laura Silver, Kat Delvin and Christine Huang, 'Unfavourable Views of China Reach Historic Highs in Many Countries', Global Attitudes \& Trends, Pew Research Center, 6 October 2020, www.pewresearch.org/global/2020/10/06/unfavorable-views-of-china-reach-historic-highs-inmany-countries/.

92018 Defence White Paper (Seoul: Ministry of National Defence, 2019); Brad Glosserman and S. Paul Choi, 'Don't Lose Sight of Under-the-Hood Changes to South Korea's Defense Posture', The Diplomat, 13 November 2019, thediplomat.com/2019/11/dont-lose-sight-of-under-thehood-changes-to-south-koreas-defense-posture/. It is important to note that, while the focus of 'omnidirectional threat' may be China, the scope of ROK perceived challenges also includes Japan and potential US abandonment.

10 Glosserman and Choi, 'Don't Lose Sight'; Chung Min Lee, 'South Korea is Caught Between China and the United States', Carnegie Endowment for International Peace, 21 October 2020; Ian Bowers and Henrik Stalhane Hiim, 'Conventional Counterforce Dilemmas: South Korea's Deterrence Strategy and Stability on the Korean Peninsula', International Security 45(3), 2021, doi.org/10.1162/isec_x_00403. 
antagonise China is, in part, a reflection of ROK perceptions and fears of US abandonment; it is also inspiring US suspicions and criticism that pose political challenges to necessary alliance planning.

\section{The North Korean Challenge}

Advancing North Korean military capabilities and adaptations to its doctrine also present formidable political-military challenges to ROK-US alliance cooperation. The Kim Jong-un regime has explicitly messaged a desire to develop and field tactical nuclear weapons that portends a shift of nuclear strategy from one of deterrence to warfighting. ${ }^{11}$ This is in addition to North Korean efforts to strengthen its option for massive retaliation against the US with solid-fuelled intercontinental ballistic missiles and a survivable second-strike submarine-launched capability.

Even before such developments, then US Secretary of Defense Robert Gates described North Korea in 2009 as posing 'a direct threat to the United States'. ${ }^{12}$ Not only did an outgoing Obama administration subsequently identify North Korea as the top national security priority for the Trump administration, but also, in 2021, the commander of US Indo-Pacific Command, Admiral Phil Davidson, considered it the most immediate threat. ${ }^{13}$ This emphasis highlights North Korea as both an extended and a central deterrence priority challenge for the US, shifting escalation dynamics and requiring adjustments to how the alliance addresses this transformed threat.

Adding to the situation's complexity is North Korea's ability to manipulate the degree of risk it poses to not only South Korea and the US, but also Japan. This allows North Korea to exploit differences in preferred approaches to deterrence between the two US allies, potentially placing the US in a dilemma, which in turn introduces further tensions into its alliances. South Korea, the US and Japan have all adjusted their force

11 Joshua Berlinger and Yoonjung Seo, 'Kim Jong Un Says North Korea Is Developing Tactical Nukes, New Warheads and a Nuclear-Powered Submarine', CNN, 9 January 2021, edition.cnn.com/2021/01/09/asia/north-korea-nuclear-development-intl-hnk/index.html.

12 Robert M. Gates, Duty: Memoirs of a Secretary at War (New York: Random House, 2015), 525.

13 Gerald F. Seib, Jay Solomon and Carol E. Lee, 'Barack Obama Warns Donald Trump on North Korea Threat', Wall Street Journal, 22 November 2016; Byun Duk-kun, 'N. Korea Poses "Most Immediate Threat" to US: Indo-Pacific Commander', Yonhap News Agency, 4 March 2021, en.yna.co.kr/view/AEN20210304000600325. 
postures. The US has also collectively advanced its deterrence cooperation with its two North-East Asian allies, but with disturbingly limited progress made in ROK-US and ROK-US-Japan strategic alignment.

North Korea's ability to threaten nuclear escalation and hold the continental US at risk exacerbates ROK concerns of alliance decoupling. For South Korea, past crises and US responses to North Korean challenges in 2010, 2015 and 2017 are assessed in this context. The 2010 sinking of the ROK navy corvette Cheonan and shelling of Yeonpyong Island are considered examples of an emboldened nuclear North Korea more confident in its ability to manage escalation to war and conduct lower-level conventional provocations without triggering major alliance responses. This has led to South Korea's pursuit of several defence reforms, including a shift in its approach to deterrence from one based on passive reactive counterforce options to active countervalue-redefined responses tailored to target the North Korean regime's decision-making calculus.

This shift manifested itself in South Korea's adoption of a 'proactive deterrence' policy and changes in its rules of engagement from 'controlled response' to 'manifold retaliation'. ${ }^{14}$ To be clear, this approach called for neither pre-emptive strikes, attacks on North Korean cities and civilians nor unlimited military responses. Rather, it aimed at responding to North Korean provocations with updated conceptions of 'in kind', 'proportionality' and 'value'-interpreted within the context of North Korea's leadership and an emphasis on what it considered of equal value or utility instead of a general definition based on equal quantity and identical means. Thus, it supported a tailored deterrence strategy aimed at altering escalation dynamics and breaking the cycle of attacks below the threshold of war under the cover of North Korea's nuclear shadow.

This South Korean approach, designed and implemented in the conservative administrations of Lee Myung-bak and Park Geun-hye, has been maintained by the progressive administration of Moon Jae-in. However, it remains a source of alliance tension, with US concern that its authorisation of 'disproportionate' responses, in the general and more traditional conceptualisation of the term, may lead to uncontrolled escalation.

14 Michael McDevitt, 'Deterring North Korean Provocations', Brookings, 7 February 2011, www.brookings.edu/research/deterring-north-korean-provocations/. 
Similarly, the two allies seemingly lacked a shared understanding of escalation dynamics and preferred responses when, in 2015, North Korea planted landmines near a known ROK border patrol path that maimed two ROK soldiers. In response, South Korea signalled resolve and capabilities to target the Kim regime's valued control of information. The ROK military set up speakers along the inter-Korea border and resumed broadcasts that promoted democracy, capitalism and life in South Korea, as well as commented on corruption and state mismanagement in North Korea. ${ }^{15}$ This was arguably a form of cross-domain countervalue-redefined activity, based on the ROK belief that information penetration would be more threatening to the Kim regime than other military options. Ironically, while both Koreas assessed this action as escalatory, some US defence officials (dismissing the utility of this soft response) initially underestimated its efficacy.

Finally, in 2017, as Kim Jong-un and then US President Donald Trump traded threats of nuclear strikes, tensions between Seoul and Washington were evident with President Moon ruling out another war on the Korean Peninsula. ${ }^{16}$ Admittedly, senior US officials denied a 'bloody nose' plan for a preventive strike on North Korea. ${ }^{17}$ Further, in emphasising the centrality of allies in US decision-making, US Joint Chiefs Chairman General Joseph Dunford stated there was 'no question' South Korea would be consulted before any military action on North Korea. ${ }^{18}$ Still, concerns remain that US 'consultation' will more closely resemble mere 'notification' as the threat North Korea poses to the US increases. Such fears are exacerbated not only by the understandable US order to 'develop credible viable military options', but also by the then commander in chief's statements about the military being 'locked and loaded', and

15 Simeon Paterson, 'Korean Loudspeakers: What are the North and South Shouting About?', $B B C$ News, 12 January 2016, www.bbc.com/news/world-asia-35278451.

16 Anna Fifield, 'No American Strike on North Korea without My Consent, Says South's President', The Washington Post, 17 August 2017, www.washingtonpost.com/world/asia_pacific/no-americanstrike-on-north-korea-without-my-consent-says-souths-president/2017/08/17/775290e8-833211e7-82a4-920da1aeb507_story.html.

17 David Brunnstrom, 'No "Bloody Nose" Plan for North Korea: US Official, Senators', Reuters, 16 February 2018, www.reuters.com/article/us-northkorea-missiles-usa-bloodynose-idUSKCN1FZ $2 \mathrm{KK}$.

18 'US to Consult Seoul before Acting Against North Korea', Straits Times, 18 August 2017. 
Senate leader Lindsey Graham stating that the damage and deaths from a war with North Korea 'would be worth it in terms of long-term stability and national security'. ${ }^{19}$

Beyond this political messaging, changes to American and Japanese capabilities also inspire ROK concerns of escalation and highlight the need for heightened cooperation in strategy design and planning integration. US development of boost-phase and left-of-launch missile defence systems, as well as new low-yield nuclear options on Trident submarine-launched ballistic missiles and future sea-launched nuclear cruise missiles, addresses some ROK concerns about potential gaps in US extended deterrence, but also requires greater shared understanding of escalation dynamics and operational implications for planned alliance operations. Similarly, Japan's stated need for a first-strike capability, accompanied by its acquisition of joint strike missiles for its F-35A stealth fighters, as well as long-range anti-ship missiles and extended-range jointair-to-surface stand-off missiles for its F-15Js, further complicates ROKUS alliance defence preparation. This is especially the case given the real threat North Korea poses to Japan, but the deficit of trust and political constraints in South Korea and Japan limit trilateral cooperation.

Like the tension in the ROK-US alliance regarding China, a similar challenge in coordinating approaches towards North Korea exists as the two allies work to align how each nation balances deterrence with diplomacy in their respective overarching strategies. The Moon government's strategic objective is to transform relations with North Korea and establish an enduring peace that no longer requires the alliance for deterrence purposes against the Kim regime. Simply, while deterrence remains an operational objective 'end' in ROK military strategy, it is not the currently preferred means to realise the higher-order national security aim of peace for this administration. Rather, many progressives in Seoul perceive the pathway to peace as consisting more of actions aimed directly at 'building' peace than at preparing for war.

Ultimately, the absence of a coherent encompassing security strategy is limiting ROK-US alliance planning. That is, the allies lack a shared understanding of escalation dynamics and of the role of deterrence in the

19 Anna Fifield and Mehdi Hasan, 'Why Does Sen. Lindsey Graham Think Killing Millions of Koreans Would Be "Worth It"?', The Intercept, 6 March 2018, theintercept.com/2018/03/06/whydo-u-s-politicians-think-killing-millions-of-koreans-would-be-worth-it/. 
transformed strategic environment. Such strategic dissonance previously existed but has become more prominent in recent ROK-US alliance management regarding China and North Korea. Thus, despite respective military preparations to address these security challenges, political divergence is constraining combined alliance preparations.

\section{Refitting Alliance Political-Military Mechanisms}

TheROK-USalliancehasa rich architecture of government-to-government political-military consultation mechanisms to address the above challenges. This includes the ROK-US Combined Forces Command and USFK Headquarters, ROK Deterrence Strategy Committee (DSC), Korea Integrated Defence Dialogue, Extended Deterrence Strategy \& Consultative Group (EDSCG), Military Committee Meeting, Security Consultative Meeting, Foreign and Defence Ministerial $(2+2)$-all of which support ad hoc coordination and cooperation between the two respective national security offices/councils and heads of state. The mechanisms, however, must be refitted to be effective. In many ways, the alliance's success and strengths are now its greatest challenges. While it perfects operational coordination and defence preparations for the traditional conventional fight against North Korea, legacy practices and processes are inhibiting necessary alliance adaptations.

The US four-star-general-led ROK-US Combined Forces Command (CFC), USFK and UN Command are examples of this. The presence of this most senior military grade officer and 28,500 permanently stationed troops on the Korean Peninsula send a strong message of US commitment to the deterrence and defence of the Korean Peninsula. Further, their presence allows for daily integrated efforts to coordinate operations and plan for common defence. This includes support for the US Office of the Secretary of Defense and interagency understanding of the 'on-the-ground' perspectives to inform US policy development.

CFC, as a warfighting command, and USFK, with its train and equip mission, are generally focused on readiness to execute wartime OPLANs. Meanwhile, UN Command, as the 'home for international commitments', works predominently to maintain the armistice. Although they do support deterrence through presence and preparations for conflict with 
North Korea, given the transformative shifts in the strategic environment, political-level strategic guidance may now be needed to update the parameters of the conflict for which they train to ensure they are preparing for the 'fight today' and not just a 'fight tonight'. Relatedly, although the ROK-US alliance established a combined counter-provocation plan and crisis action standard operating procedures to address challenges below the threshold of war, even these two mechanisms are operated with questionable consideration to the influence of North Korea's advancing asymmetric capabilities.

Policy coordination mechanisms-such as the DSC, EDSCG and 2+2appropriately consist of representatives from both diplomatic and defence ministries/departments. Nevertheless, these fora are sometimes criticised as 'a lot of process, but no progress'. While their establishment alone once represented progress in facilitating alliance cohesion, transformed deterrence challenges now require their agendas be updated to tackle the implications of China's rise and a changing North Korean nuclear posture.

As China and North Korea cast shadows over and beyond the traditional scope of ROK-US security cooperation, the alliance needs to widen its aperture and raise the level of its discussions to address these shifts in the security environment. This includes strengthening strategic alignment on how to strengthen deterrence in peacetime through war. In particular, the allies must address the transforming challenges that for past and present reasons pose political tensions in the alliance. Ultimately, South Korea and the US must adapt the ways in which they cooperate and wage deterrence. Failure to do so will have the alliance operationally ready only for a conflict of the past and at risk of strategic defeat in the transformed campaign in which it must now actively engage. 
This text is taken from Alliances, Nuclear Weapons and Escalation: Managing Deterrence in the 21st Century, edited by Stephan Frühling and Andrew O'Neil, published 2021 by ANU Press, The Australian National University, Canberra, Australia.

doi.org/10.22459/ANWE.2021.07 